\title{
A survey of dairy calf management practices in Canada that affect animal welfare
}

\author{
E. Vasseur, ${ }^{* 1}$ F. Borderas, †‡ R. I. Cue,§ D. Lefebvre,\# D. Pellerin, ${ }^{\star}$ J. Rushen, $\|$ K. M. Wade,§ \\ and A. M. de Passillé\| \\ *Department of Animal Sciences, Laval University, Quebec City, Quebec, Canada, G1K 7P4 \\ †Animal Welfare Program, University of British Columbia, Vancouver, British Columbia, Canada, V6T $1 Z 4$ \\ łDepartamento de Produccion Agrícola y Animal, Universidad Autónoma Metropolitana-Xochimilco, Mexico City, Mexico, 04960 \\ §Department of Animal Science, McGill University, Montreal, Quebec, Canada, H9X 3V9 \\ \#Valacta, Dairy Production Centre of Expertise Quebec-Atlantic Canada, Sainte-Anne-de-Bellevue, Quebec, Canada, H9X 3R4 \\ \|Pacific Agri-Food Research Centre, Agriculture and Agri-Food Canada, Agassiz, British Columbia, Canada, V0M 1A0
}

\section{ABSTRACT}

There is growing interest among the public in farm animal welfare and a need for methods to assess animal welfare on farm. A survey on calf rearing practices that might affect dairy calf welfare was performed via a 1 -h interview on 115 dairy farms (mean \pm SD: herd size $=$ $52.5 \pm 20.9$ cows; milk production $=8,697 \pm 1,153 \mathrm{~L}$ ) distributed throughout the province of Quebec. Despite frequent recommendations, many dairy producers continue to use management practices that increase the health risks of milk-fed calves. Major risk factors for poor calf welfare identified were 1) no use of calving pen in $51.3 \%$ of herds and low level of surveillance of calvings, especially at nighttime (once every $12 \mathrm{~h}$ ), 2) no disinfection of newborn's navel in $36.8 \%$ of herds, and delayed identification and, hence, calf monitoring (3 d), 3$) 15.6 \%$ of farms relied on the dam to provide colostrum and none checked colostrum quality or passive transfer of immunity, 4) dehorning and removal of extra teats proceeded at late ages $(6.4 \mathrm{wk}$ and $6.7 \mathrm{mo}$, respectively) and without adequate pain control, 5) use of traditional restrictive milk feeding and waste milk distributed to unweaned calves without precaution in $48.2 \%$ of herds, 6 ) abrupt weaning performed in $16.5 \%$ of herds, and 7) calves housed individually in $87.9 \%$ of herds, and most inappropriate housing systems (crate $=27.0 \%$, tie-stall $=13.9 \%$, attached against a wall $=$ $5.7 \%)$ remained. This risk factor assessment was the first step in an intervention strategy to improve calf welfare on dairy farms.

Key words: calf, management, welfare, risk factor

Received May 28, 2009.

Accepted December 4, 2009.

${ }^{1}$ Corresponding author: vasseur.elsa@gmail.com

\section{INTRODUCTION}

Public concern about animal welfare remains high in Europe and is increasing in North America (e.g., Pew Commission, 2008), as witnessed by the passage of proposition 2 in California (Office of the Attorney General, 2008). Typically, there are large differences among farms in the level of animal welfare achieved, which has led to several attempts to develop methods of assessing animal welfare on farm for dairy cows (e.g., Webster, 2005). Despite the importance of financial costs of rearing management (Mourits et al., 1997, 1999; Pellerin and Gilbert, 2008) and the long-term effects of the rearing period in the life of the future dairy cows (e.g., Shamay et al., 2005), calf mortality and morbidity remain high in North America (USDA, 2008) and there have been few attempts to develop onfarm welfare assessments for dairy calves.

The public's concern about animal welfare touches upon the health of the animal, the extent that the animal suffers from pain or aversive emotions, and the ability of the animal to perform most normal behaviors (Fraser et al., 1997; Rushen et al., 2008). This is reflected in many definitions of animal welfare (e.g., World Organization for Animal Health, 2008) and animal welfare assessment needs to cover all 3 areas of concern. There is also growing interest in ensuring that animals can experience positive welfare (e.g., Yeates and Main, 2008); in the future, animal welfare assessments may also consider this fourth area of concern.

The European Food Safety Authority has developed a risk analysis approach to animal welfare and has carried out a risk analysis of calf welfare (European Food Safety Authority, 2006). This approach requires a characterization of the major hazards for animal welfare and an assessment of the likelihood of animals being exposed to each hazard. The first step in an animal welfare assessment, therefore, is to describe the most commonly used management practices that may be a 
Table 1. Characteristics of the 115 farms surveyed compared with all farms in Quebec and Canada ${ }^{1}$

\begin{tabular}{lccc}
\hline Item & Sample & Quebec & Canada \\
\hline No. of farms & 115 & 5,515 & 10,618 \\
Herd size $^{2}$ no. of cows & $52.5 \pm 20.9$ & 53.6 & 65.9 \\
Herd milk production, $^{2} \mathrm{~kg} /$ cow per year & $8,697 \pm 1,153$ & 8,246 & 8,374 \\
\hline
\end{tabular}

${ }^{1}$ Data for Quebec and Canada from Valacta (2007).

${ }^{2}$ Mean value \pm SD.

hazard for animal welfare. In this study, we surveyed dairy farms in Quebec to obtain data on the prevalence of calf rearing practices that may affect animal welfare.

\section{MATERIALS AND METHODS}

\section{Selection and Description of Herds}

We surveyed calf and heifer rearing methods on 115 dairy farms that were distributed throughout the province of Quebec (including 12 of the 18 agricultural territories of Quebec) and selected to be representative of farms in Quebec in terms of size, milk production, and housing method. The size and milk production of the farms is shown in Table 1. On all farms, lactating Holstein cows were kept in tie-stalls, which is the type of housing used by $90 \%$ of dairy farms in Quebec [Ministère de l'Agriculture, des Pêcheries et de l'Alimentation du Québec (MAPAQ), Quebec City, Quebec, Canada]. The farms were selected on the basis of membership in Valacta, which is the dairy herd analysis system for Quebec and Atlantic provinces.

\section{Collection and Description of Data}

Data were collected during the fall and winter from 60 farms in 2005, 40 in 2006, and 25 in 2007. The onfarm survey included a face-to-face interview with the farm manager by a trained Valacta agent, who was the regular farm advisor, using a standard questionnaire.
We developed a questionnaire, which consisted of multiple-choice and semiclosed questions, to clarify the questions and to facilitate the interview by reducing the time needed and improving homogeneity of answers (Malhotra, 2006). The questionnaire included some topics from the following United States National Animal Health Monitoring System studies: National Dairy Heifer Project 1991-1992 (USDA, 1994) and National Animal Health Monitoring System Dairy 1996 (USDA, 1997) and 2002 (USDA, 2003). We added some questions and modified others after consultation with regional specialists of Valacta that would later train the advisors doing the survey on the farms they visited. The new version of the questionnaire was tested on 5 farms to check the feasibility, which showed that the interview could be completed in about $1 \mathrm{~h}$.

The questionnaire was divided into 7 groupings of management practices that could affect calf welfare (Table 2): calving management and care of the newborn, colostrum management, calf-dam separation, painful procedures, calf feeding, weaning, and calf housing. The answers to the questions (data) were qualitative nominal (e.g., yes or no), qualitative ordinal (e.g., scale of answers from $1=$ never to $5=$ always), or continuous (e.g., number of liters of colostrum).

\section{Statistical Analysis}

The questionnaires returned were individually examined for aberrant results, and the answer was excluded when a question was obviously misunderstood. Descrip-

Table 2. Targeted area of management and variables of the questionnaire on calf management

\begin{tabular}{|c|c|}
\hline Area of management & Variable \\
\hline $\begin{array}{l}\text { Calving management } \\
\text { and care of the newborn }\end{array}$ & $\begin{array}{l}\text { Calving area: use of calving pen, type, use as hospital pen. Calving checks: use of camera, number } \\
\text { of visits a.m., number of visits p.m., time of navel disinfection, time of calf identification. }\end{array}$ \\
\hline Colostrum management & $\begin{array}{l}\text { Time of the first colostrum meal; method, quantity, number, and duration of colostrum meals; } \\
\text { colostrum origin; stocks of colostrum; evaluation of colostrum quality; evaluation of passive transfer }\end{array}$ \\
\hline Calf-dam separation & Time of the separation \\
\hline Painful procedures & Dehorning: age, method, use of analgesic and anesthetic. Teat removal: age, method, use of analgesic. \\
\hline Calf feeding & $\begin{array}{l}\text { Milk: type, use of pasteurization, use of waste milk. Milk feeding plan: quantity and number } \\
\text { of meals, method of distribution. Water: age and type of access, type of drinker. Concentrate: } \\
\text { age at access, quantity and number of meals. Roughage: type, age and type of access, quantity. }\end{array}$ \\
\hline Weaning & Criteria, age, weight, concentrate consumption, type \\
\hline Calf housing & Individual housing, indoor housing, type, covering material and litter \\
\hline
\end{tabular}


Table 3. Reported intervals between visits to the calving areas when cows were expected to calve during the daytime and nighttime

\begin{tabular}{|c|c|c|c|c|c|c|}
\hline Survey answer & No. of herds & Minimum & 25th percentile & Median & 75th percentile & Maximum \\
\hline Reported average interval between 0600 and $1800 \mathrm{~h}, \mathrm{~h}$ & 114 & 0 & 6 & 4 & 3 & 1 \\
\hline Reported average interval between 1800 and $0600 \mathrm{~h}, \mathrm{~h}$ & 115 & 0 & 12 & 12 & 6 & 1 \\
\hline
\end{tabular}

tive statistics were calculated: the percentage of farms giving a particular response (in the case of qualitative questions) and the minimum, 25th percentile, median, 75th percentile, and maximum values for continuous variables.

\section{RESULTS AND DISCUSSION}

\section{Calving Management and Care of the Newborn}

The conditions at calving represent a major hazard for the health of the newborn calf. Calving requires special facilities (such as a calving pen) designed to minimize stress and ensure the comfort and hygiene of the cow and newborn calf. In $51.3 \%$ of surveyed herds, calving pens were not used; instead, the cows calved in tie-stalls. Similar practices exist in the United States, where $29.9 \%$ of farms do not have a calving area (USDA, 2008). A cow tied during parturition is not able to move freely to find comfortable positions to adapt herself for the delivery; this comfort is even more important for heifers (Mee, 2004). A lack of hygiene is also of concern because calves can be born in the manure gutter behind tie-stalls. Group calving pens were used by only $1.7 \%$ of respondents, a much smaller proportion than in the United States, where $70 \%$ of farms use this type of calving environment. In dairy herds, diarrhea (Frank and Kaneene, 1993), respiratory problems (Svensson et al., 2003), and the risk of Salmonella infections (Losinger et al., 1995) is lower when calving occurs in individual calving pens compared with in group settings. More than half $(52.8 \%)$ of herd owners used the calving pens to house sick animals, which is comparable to the United States (34.2\%). Allowing sick cows in calving areas is a potential source of disease for other cows and newborn calves.

Regular surveillance of cows about to calve is necessary to ensure assistance at calving when difficulties occur, to reduce perinatal mortality (Mee, 2004), and to ensure that the calf receives its first colostrum feeding no more than $6 \mathrm{~h}$ after birth (National Farm Animal Care Council, 2009). On average, producers visited cows that were expected to calve 3 times (once every $4 \mathrm{~h}$ ) between morning and evening milkings, but only once (once every $12 \mathrm{~h}$ ) between evening and morning milkings (Table 3). Less than $7.8 \%$ of surveyed farms used a camera to monitor calvings. von Keyserlingk and Weary (2007) reported that many occur during the night, so this level of supervision may be unsuitable for cows at parturition and may also explain the large number of calves that are not born in the provided calving pens in United States herds (USDA, 2008).

In $36.8 \%$ of herds surveyed, the disinfection of the newborn's navel was not done despite recommendations (National Farm Animal Care Council, 2009). Although it has not been proven in controlled experiments, it is generally recognized that early disinfection accelerates drying up of the umbilicus to reduce infections so that calf morbidity (respiratory and enteric diseases) and mortality are decreased (Quigley et al., 1996).

Calves were first identified at a median age of $3 \mathrm{~d}$ (Table 4). An immediate identification of the newborn should facilitate individual follow-up and therefore improve care of the newborn calf (Quigley et al., 1996). In Quebec, traceability regulations require producers to affix permanent identification tags within $7 \mathrm{~d}$ of birth.

In summary, a considerable number of farms did not use a dedicated calving pen, and surveillance intensity of calvings was quite low, especially during the nighttime. Identification of the calves was delayed in most cases. The majority of producers disinfected the navel of the newborn calf.

\section{Colostrum Management}

Inadequate colostrum management remains one of the most serious hazards for calf welfare (European Food Safety Authority, 2006). The timing of the first meal of colostrum is critical because optimal absorption of immunoglobulins occurs before $4 \mathrm{~h}$ of age and decreases

Table 4. Reported age at which calves were dehorned and identified and extra teats were removed

\begin{tabular}{lccccc}
\hline Survey answer & No. of herds & Minimum & 25th percentile & Median & 75 th percentile \\
\hline Age at identification, d after birth & 115 & 1 & 1 & 3 & 7 \\
Age at dehorning, wk after birth & 115 & 0.1 & 4.3 & 6.4 & 4.6 \\
Age at teat removal, mo after birth & 99 & 0.3 & 4.2 & 6.7 & 28.2 \\
\hline
\end{tabular}


Table 5. Reported quantity of colostrum given, number of meals of colostrum, and duration of colostrum feeding period

\begin{tabular}{|c|c|c|c|c|c|c|}
\hline Survey answer & No. of herds & Minimum & 25th percentile & Median & 75th percentile & Maximum \\
\hline Colostrum quantity during h $12-24, \mathrm{~L}$ & 113 & 0 & 2 & 2 & 4 & 12 \\
\hline Colostrum meals, $\mathrm{n}$ & 114 & 1 & 2 & 2 & 2 & 4 \\
\hline
\end{tabular}

rapidly after $12 \mathrm{~h}$ (Weaver et al., 2000). Most herds $(94.8 \%)$ gave a first meal in the first $6 \mathrm{~h}$ after birth, and $40.9 \%$ of those gave a first meal in the first $2 \mathrm{~h}$ after birth. However, these values most likely reflect the time from when the calf was found rather than actual birth time. Given the relatively low level of surveillance at nighttime (Table 3), it is likely that many calves received their first hand-fed colostrum more than $6 \mathrm{~h}$ after birth. These results are similar to those of a recent United States survey that reports that $43.6 \%$ of farms feed calves colostrum within $2 \mathrm{~h}$ after birth, and $51 \%$ feed colostrum between 2 and $6 \mathrm{~h}$ after birth (Kehoe et al., 2007).

In $15.6 \%$ of the farms surveyed, calves were left to nurse for colostrum: $7.8 \%$ left the calf with the dam without intervention and another $7.8 \%$ left the calf with the dam with intervention (i.e., caretakers helped the calf to suckle the dam). Nursing for colostrum is found even more widely in the United States: $36.6 \%$ of United States herds let calves nurse for colostrum (USDA, 2008). Calves that get colostrum only during nursing may not receive a proper quality or amount of colostrum in a timely manner, which increases risks of failure of passive transfer (Franklin et al., 2003). Svensson et al. (2003) noticed that calves obtaining their colostrum only by suckling suffer from higher incidences of diarrhea, which could also be the result of low colostrum intake.

The method of colostrum feeding can have an effect on calf welfare. For example, Hänninen et al. (2007) showed that sucking colostrum from a teat bucket compared with drinking from an open bucket improves calf rest and sleep. A bottle with a teat was used to feed colostrum in $51.3 \%$ of the herds surveyed, and $36.5 \%$ used a simple bucket.

Feeding colostrum with an esophageal tube is still marginal in North America. We found that only 9.6\% of herds surveyed occasionally used a tube, which is slightly higher than in United States herds (4.3\%, USDA, 2008). Tube feeding may be a suitable alternative in the case where newborn calves have difficulties voluntarily drinking the recommended amount. Vasseur et al. (2009a) reported that $22 \%$ of Holstein calves of 2 to $6 \mathrm{~h}$ of age are unable to bottle-drink $2 \mathrm{~L}$ of colostrum in a first meal.
In Holstein calves, Weaver et al. (2000) consider a minimum quantity of $4 \mathrm{~L}$ of colostrum to ensure a sufficient absorption of immunoglobulins (100 mg) and subsequently reduce the risk of mortality. The majority of herds met this goal (median colostrum quantity during the first $12 \mathrm{~h}=2.5 \mathrm{~L}$; median colostrum quantity during h $12-24=2.0 \mathrm{~L}$; Table 5). The amounts of colostrum fed are somewhat higher than in the United States: only $30.9 \%$ of United States farms that normally handfed colostrum (19.6\% of all herds) fed $3.78 \mathrm{~L}$ (4 quarts) or more, whereas $23.3 \%$ ( $14.8 \%$ of all farms) fed $1.89 \mathrm{~L}$ (2 quarts) or less during the first $24 \mathrm{~h}$ (USDA, 2008).

All surveyed farms (100\%) provided colostrum from the dam and only $3.5 \%$ used colostrums from a pool. In contrast, in the United States (USDA, 2008), 21\% of farms use colostrum from a pool. Weaver et al. (2000) do not recommend the use of pools because pooling colostrum may increase calves' exposure to pathogens. Fresh colostrum was used (98.3\%), and only $32.2 \%$ of farms had stocks of colostrum. Using only fresh colostrum and having no frozen stocks is not recommended and shows a lack of awareness of the importance of timely colostrum feeding. Weaver et al. (2000) encourage the use of colostrum from primiparous cows because of the lack of significant differences in concentration of immunoglobulins between parities. In the herds surveyed in our study, colostrum from primiparous cows was used in $94.7 \%$, which is slightly higher than in United States dairy herds (78\%; Kehoe et al., 2007).

Using a colostrometer is an easy on-farm method (Vasseur et al., 2009b) to estimate the concentration of antibodies in colostrum and to ensure provision of high-quality colostrum. Measuring immunoglobulin concentrations in the calf's blood is the only method for evaluating passive transfer of immunity. No producers in our survey evaluated the quality of the colostrum or assayed immunoglobulin concentrations in the calf's blood even though commercial, easy-to-use tests are available (Dawes et al., 2002). This is lower than in United States herds, where 13.0\% of farms that handfed colostrum ( $8.3 \%$ of all farms) evaluated colostrum quality before feeding and $43.7 \%$ of them $(3.6 \%$ of all farms) estimated the immunoglobulin levels by a colostrometer (USDA, 2003). Measuring passive transfer is more frequent in the United States: $2.1 \%$ of farms 
routinely measured passive transfer via serum proteins (USDA, 2008); this percentage increased to $14.5 \%$ for larger farms.

In summary, most producers fed adequate quantities of colostrum, but a significant minority still fed less than recommended amounts. Some producers continued to rely on the calf suckling the dam, and few producers checked the quality of the colostrum. No producers checked the immunoglobulin status of the calf. Although producers reported giving colostrum in a timely manner, it is likely that many calves received colostrum at a later than optimal age because of the low level of calving surveillance during the night.

\section{Calf-Dam Separation}

Immediate separation of the calf from the dam is usually recommended to decrease risk of exposure to environmental pathogens (Windsor and Whittington, 2009), to facilitate first care, and to control colostrum feeding. In contrast, separation from the dam was identified by the European Food Safety Authority (2006) as a main risk for calf welfare because of the lack of maternal care. In addition, delayed separation (after 14 d) induces better weight gain and better calf health and influences the development of the calf's social behavior compared with separation at $1 \mathrm{~d}$ (after separation, calves were bucket-fed $10 \%$ of their BW; Flower and Weary, 2001). However, if separation from the dam is a distress for the calf (and the cow), the effect of breaking the bond becomes more evident the longer the calf stays with the cow (Flower and Weary, 2001).

In $73.2 \%$ of the herds surveyed, the calf was separated from the dam before $12 \mathrm{~h}$ of age and $32.5 \%$ separated before $2 \mathrm{~h}$. Immediate separation is more frequent in the United States (55.9\% of herds; USDA, 2008). Seven percent of Quebec herds separated calf and dam after $24 \mathrm{~h}$; similarly, this practice includes $7.3 \%$ of herds in the United States (USDA, 2008). In summary, separation of the calf from the cow was done early in most cases.

\section{Painful Procedures}

Painful procedures, such as dehorning, are of particular concern to the public (Rushen et al., 2008), and the Canadian Dairy Code of Practice (National Farm Animal Care Council, 2009) requires the use of pain control when painful procedures are performed. Research has shown clearly that dehorning and disbudding are painful and that a combination of local anesthetics and longer lasting analgesics are necessary to reduce both the pain during the operation and postoperative pain (Stafford and Mellor, 2005). After 3 mo, dehorning must be per- formed by surgery (Sylvester et al., 1998). Disbudding when the calf is less than 3 wk of age is recommended (National Farm Animal Care Council, 2009) because it allows the use of less-painful methods such as chemical paste, for which pain is easier to control (Vickers et al., 2005). Dehorning was done at a median age of 6.4 wk (Table 4); there was a wide variation among farms, but $25 \%$ of surveyed farms dehorned after 3 mo. The most common method of dehorning $(88.7 \%)$ was the use of a hot iron. Surgery was used in $7.0 \%$ of herds, and a chemical method in $6.1 \%$ of herds. Anesthetic use during dehorning was reported in $44.7 \%$ of herds, but none reported using analgesic. Similarly, a recent survey conducted on Ontario dairy herds showed that only $21 \%$ of producers dehorned before 4 wk of age, whereas $37 \%$ dehorned after 8 wk and $22 \%$ used local anesthetics (Misch et al., 2007).

Supernumerary teats were removed at a median age of $6.7 \mathrm{mo}$, but there was a large variation among farms (Table 4). Veterinarians were in charge of teat removal in $81.9 \%$ of surveyed herds. A chisel was the method most used (63.7\%), and $24.5 \%$ used a scalpel. Few surveyed farms (6.8\%) used anesthetics during teat removal. In summary, dehorning and removal of extra teats were both done at a late age and the majority of producers report not using pain control (no use of anesthetic or analgesic) during these procedures.

\section{Calf Feeding}

Recent studies (Jasper and Weary, 2002; Rincker et al., 2006; Khan et al., 2007) show benefits of feeding calves larger amounts of milk than the traditional 10 to $12 \%$ of $\mathrm{BW} / \mathrm{d}$, such as increasing growth, improved mammary development, accelerated age at first calving, and increasing milk production during first lactation, whereas there is evidence that calves suffer from hunger with a restrictive diet (De Paula Vieira et al., 2008; Borderas et al., 2009). In contrast, the milk feeding plan used in the surveyed herds (Table 6) was a median of $4 \mathrm{~L}$ of milk or milk replacer per day given in 2 meals during the first week, $5.5 \mathrm{~L}$ in 2 meals between the first and the last week before weaning, and $3 \mathrm{~L}$ in 2 meals during the last week of milk feeding.

Producers should be cautious about using unpasteurized waste milk and milk from cows on antibiotics (Selim and Cullor, 1997) because of the increased risk for transmission of infectious pathogens to cattle and humans. Even pasteurization is not totally effective in eliminating pathogenic bacteria (Godden et al., 2003). The problem could be even more important for newborn calves, especially when no control of passive transfer of immunity is in place. However, unpasteurized milk from cows on antibiotics was given (often to sometimes) by 
Table 6. Reported quantities of milk (or substitute) and number of meals distributed during the first week, between the first and the last week, and during the last week of milk feeding

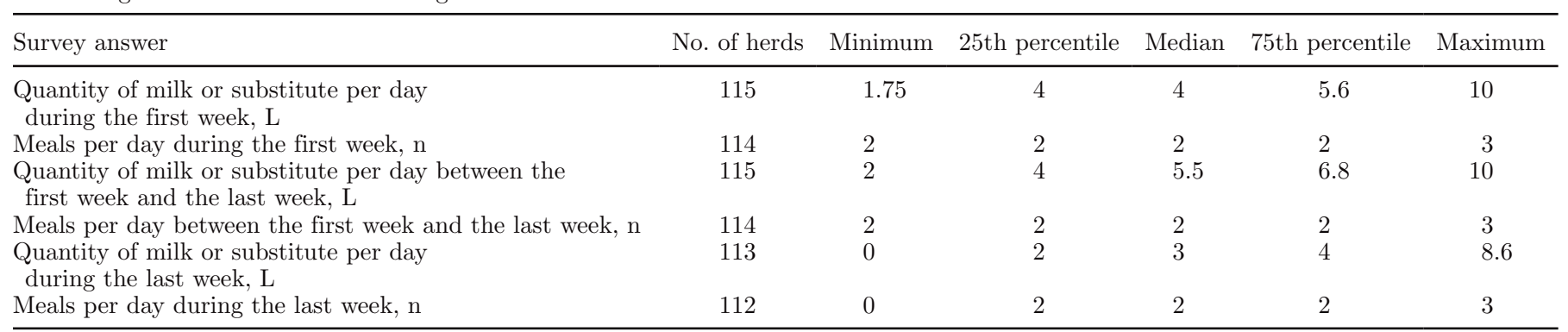

$47.7 \%$ of surveyed farms and unpasteurized waste milk by $48.2 \%$. Pasteurization was not used by any farms in the study. Similarly to Quebec farms, unpasteurized waste milk is given by $30.6 \%$ of United States farms (USDA, 2008). Pasteurization is also infrequent (1.4\% fed pasteurized whole milk) but increases with herd size (28.7\% of large operations fed pasteurized waste milk; USDA, 2008).

Some studies show advantages of whole milk as compared with milk replacer: lower mortality and morbidity (Godden et al., 2005), higher energy content, and better balance of nutrients (Davis and Drackley, 1998). Also, a variety of hormones and growth factors in milk are not incorporated into milk replacer. Unpasteurized whole (marketable) milk was given (often to sometimes) by $89.0 \%$ of farms and milk replacer was given by $50.0 \%$. The reason cited to feed fresh milk was "less difficult" by $70.1 \%$ of farms, "using waste milk" by $42.5 \%$, "using milk produced over the available quota" by $36.8 \%$, and "better growth" by $23.0 \%$. In contrast, milk replacer is the main type of liquid diet in the United States (57.5\% fed medicated milk replacer and $12.7 \%$ fed nonmedicated) whereas unpasteurized whole (marketable) milk is fed by $28 \%$ of farms (USDA, 2008).

Calves are highly motivated to suck, and allowing calves to suck has been shown to increase satiety, increase secretion of hormones important for digestive function and satiety, increase the time calves sleep, and reduce nonnutritive sucking (reviewed in Rushen et al., 2008). Bucket-fed calves are unable to perform their natural sucking behavior, but teat-based milk feeding systems provide such an opportunity. A bucket was used to feed milk by $92.0 \%$ of producers, and bottle with teat by only $17.7 \%$. Despite the demonstrated advantages of feeding larger amounts of milk, most farms in our study continue to apply traditional restrictive milk feeding (e.g., bucket fed low quantities of milk or replacer twice daily).

Calves becoming ruminant animals require a physically and functionally developed rumen to consume forages and grain. In the herds surveyed, calves had access to concentrate (Table 7) at a median age of $7 \mathrm{~d}$ after birth and the median amount offered was $1 \mathrm{~kg}$. Ad libitum grain access was provided by $65.5 \%$. Hay was provided by all farms after $3 \mathrm{~d}$ of age and at a quantity of $0.5 \mathrm{~kg}$. Ad libitum access to hay was provided by $63.0 \%$. No farms reported offering hay silage or corn silage to unweaned calves. Amounts of grain and hay fed were known only by 40.0 and $70.0 \%$ of surveyed farmers, respectively. In the United States, average age for grain access is similar to Quebec herds $(8.5 \mathrm{~d})$ but access to forage is postponed to $24.5 \mathrm{~d}$ (USDA, 2008).

Free water intake is essential for proper rumen function and for early intake of dry feed and should therefore be made available within the first week of life (Kertz et al., 1984). In our study, $9.6 \%$ of farms reported not giving unweaned calves access to water. Where calves had access to water (Table 7), this was at a median age of $2.5 \mathrm{~d}$ after birth. A bucket was provided by $54.1 \%$ of farms and an automatic drinker by $45.0 \%$. In the United States (USDA, 2008), calves have free water access later than in Quebec, at $15.3 \mathrm{~d}$ of age on average. Feeding milk or replacer should not be a substitute for water.

Table 7. Reported age at access and quantity of supply for water, concentrate, and hay

\begin{tabular}{lccccc}
\hline Survey answer & No. of herds & Minimum & 25th percentile & Median & 75th percentile \\
\hline Age at water access, d after birth & 105 & 1 & 1 & 2.5 & 7 \\
Age at concentrate access, d after birth & 113 & 1 & 3 & 7 & 60 \\
Quantity of concentrate supply, kg & 45 & 0.25 & 1 & 1 & 120 \\
Age at hay access, d after birth & 114 & 0.7 & 1 & 3 & 2 \\
Quantity of hay supply, kg & 77 & 0.1 & 0.3 & 0.5 & 6 \\
\hline
\end{tabular}


Table 8. Reported average age, BW, and concentrate intake at weaning

\begin{tabular}{|c|c|c|c|c|c|c|}
\hline Survey answer & No. of herds & Minimum & 25th percentile & Median & 75th percentile & Maximum \\
\hline BW at weaning, $\mathrm{kg}$ & 103 & 50 & 72 & 82 & 92 & 220 \\
\hline
\end{tabular}

In summary, most herds continued to give only 10 to $12 \%$ of BW of milk or replacer per day despite the demonstrated advantages of feeding calves larger volumes of milk. Almost half of the Quebec surveyed farms fed waste milk without proper handling or pasteurization. Beside these weak points, immediate water access was found in most farms, as was early access (first week of age) to solid feed. Early access to forage may delay starter intake and rumen development (Davis and Drackley, 1998).

\section{Weaning}

Weaning off milk is the first major feeding transition for young heifers and is particularly stressful for the animal and challenging for the producer. Weaning should be gradual and based on the calf's ability to eat solid food. In commercial conditions, dairy calves are normally weaned at much younger ages than in the wild, which is around 6 mo (Phillips, 2001). Weaning should be managed to avoid decreased nutrient intake and weight loss as well as frequent vocalization, which is a sign of weaning distress (Weary et al., 2008).

Age was used by $66.7 \%$ of farms as the main criteria for weaning, whereas concentrate intake was used by $43.9 \%$. Gradual weaning was used by $89.6 \%$ of farms, and the main method $(60.0 \%)$ was progressively reducing the quantity of milk or substitute. However, $16.5 \%$ used abrupt weaning. The median age at weaning was 7 wk (Table 8), the median BW was $82 \mathrm{~kg}$, and the median concentrate intake was $2 \mathrm{~kg}$. The large values obtained from some farms (e.g., age $=28 \mathrm{wk}$; BW $=$ $220 \mathrm{~kg}$; concentrate intake $=4.5 \mathrm{~kg}$ ) were from organic herds. The average age at weaning is higher in the United States, at 8.2 wk (USDA, 2008). In summary, most producers weaned their calves gradually but used age rather than concentrate intake as criteria to wean.

\section{Calf Housing}

One of the most contentious calf welfare issues is the use of individual housing (Rushen et al., 2008). We found that $87.9 \%$ of surveyed farms housed unweaned calves individually. Similarly, most herds housed calves individually in the United States (USDA, 2008): $67.9 \%$ in individual pens or hutches and $8.9 \%$ in tie-stalls.
Group housing is compulsory for calves older than 8 wk by European Union regulations (Council of the European Union, 1997). The claimed advantages of individual housing are reduced transmission of diseases. However, epidemiological research suggests that it is the use of large groups, rather than of group housing itself, that is responsible for increased calf mortality and morbidity (Losinger and Heinrichs, 1997; Svensson et al., 2003). The advantages of group housing are also uncertain; however, recent studies suggest that there may be some benefits of keeping dairy calves in groups, such as increased opportunities for social interactions and greater access to space, which facilitates physical exercise and allows more normal behavior (Jensen et al., 1997; Chua et al., 2002).

The use of outdoor hutches for housing dairy calves is widespread in North America and is now the most common type of outdoor housing for dairy calves in the United States (USDA, 2008). We found that $79.6 \%$ of surveyed farms housed unweaned calves in the main barn, $12.4 \%$ in a calf barn, and only $8.0 \%$ outdoors. If indoor environments might be expected to have some disadvantages for calf health (e.g., many animals are sharing the same airspace, increasing the risk of airborne disease transmission), outdoor-housed calves are exposed to greater variation in environmental conditions (e.g., hot and cold temperature, wind and rain). Cold environment could be a potential health hazard (e.g., higher risk of diarrhea) for calves even if calves can tolerate relatively low temperature (Hänninen et al., 2003).

Unweaned calves were housed in pens (with barriers or solid walls) in $45.9 \%$ of surveyed farms, $27.0 \%$ in metal or wood crates, $13.9 \%$ in tie-stall, $7.4 \%$ in hutches, and $5.7 \%$ were tied to the wall in front of cows' tie-stalls. The Canadian Dairy Code of Practice (National Farm Animal Care Council, 2009) requires that housing allows calves to easily stand up, lie down, turn around, adopt normal resting postures, and have visual contact with other calves. It is unlikely that many of the types of housing used (i.e., crates, tie-stall, or tying against a wall) met these requirements.

Adequate rest appears important for the growth of calves (e.g., the longer the calves rest, the better they grow); however, the softness of the floor (concrete vs. rubber mat) has little effect on growth and resting be- 
havior (Hänninen et al., 2005). In surveyed farms, the floor of housing for nonweaned calves was mainly solid concrete $(74.4 \%)$ or rubber mattresses $(11.6 \%)$. Bedding was mainly straw or hay $(65.4 \%)$ or shaving (30.1\%). In summary, most producers housed calves individually and many used inappropriate housing systems (crate, tie stall, or even attached against a wall).

\section{CONCLUSIONS}

We identified good practices in calf management, but some risks factors in term of welfare have been also identified. These were 1) low use of a dedicated calving pen and infrequent surveillance of calvings, 2) no disinfection of newborn's navel and delayed identification and, hence, delayed calf monitoring, 3) relying on suckling as a source of colostrum, or delaying and providing insufficient quantities, and unchecked immunoglobulin quality and immunity transfer, 4) dehorning and removing supernumerary teats at late age and without pain control, 5) waste milk given without precaution and traditional restrictive feeding of milk or substitute, 6 ) weaning targeted on age rather than on concentrate intake, and 7) calves housed individually and in inappropriate housing systems.

This survey concentrated on risk factors for poor welfare. However, there is growing interest in ensuring that animals can experience positive welfare (e.g., Yeates and Main, 2008), and this may be necessary to consider in future surveys. This management survey helps us to understand the practices we need to focus on in our intervention strategy to improve calf welfare in Quebec dairy farms. Some surveyed farms followed recommended practices. We detected 6 areas of calf management that needed improvement: calving management and care of the newborn, colostrum management, painful procedures, calf feeding, weaning, and calf housing.

\section{ACKNOWLEDGMENTS}

This study was supported by a grant from the Action concertée Fonds Québecois de la Recherche sur la Nature et les Technologies (FQRNT; Quebec City, Quebec, Canada) - Novalait (Quebec city, Quebec Canada) - Ministère de l'Agriculture, des Pêcheries et de l'Alimentation du Québec (MAPAQ; Quebec City, Quebec Canada) in collaboration with Agriculture and Agri-Food Canada (Ottawa, Ontario, Canada). We thank Valacta (Sainte-Anne-de-Bellevue, Quebec, Canada) advisors for their technical assistance and the producers for their participation.

\section{REFERENCES}

Borderas, T. F., A. M. de Passillé, and J. Rushen. 2009. Feeding behavior of calves fed small or large amounts of milk. J. Dairy Sci. 92:2843-2852.

Chua, B., E. Coenen, J. van Delen, and D. M. Weary. 2002. Effects of pair verses individual housing on the behavior and performance of dairy calves. J. Dairy Sci. 85:3360-3364.

Council of the European Union. 1997. Council Directive 97/2/EC of 20 January 1997 amending Directive 91/629/EEC laying down minimum standards for the protection of calves. Official Journal of the European Communities, Brussels, Belgium.

Davis, C. L., and J. K. Drackley. 1998. The Development, Nutrition, and Management of the Young Calf. Iowa State Univ. Press, Ames.

Dawes, M. E., J. W. Tyler, D. Hostetler, J. Lakritz, and R. Tessman. 2002. Evaluation of commercially available immunoassay for assessing adequacy of passive transfer in calves. J. Am. Vet. Med. Assoc. 220:791-793.

De Paula Vieira, A., V. Guesdon, A. M. de Passille, M. A. G. von Keyserlingk, and D. M. Weary. 2008. Behavioural indicators of hunger in dairy calves. Appl. Anim. Behav. Sci. 109:180-189.

European Food Safety Authority. 2006. The risks of poor welfare in intensive calf farming systems. An update of the Scientific Veterinary Committee Report on the Welfare of Calves. EFSA-Q-2005-014. European Food Safety Authority, Parma, Italy.

Flower, F. C., and D. M. Weary. 2001. Effects of early separation on the dairy cow and calf: 2 . Separation at 1 day and 2 weeks after birth. Appl. Anim. Behav. Sci. 70:275-284.

Frank, N. A., and J. N. Kaneene. 1993. Management risk factors associated with calf diarrhea in Michigan dairy herds. J. Dairy Sci. 76:1313-1323

Franklin, S. T., D. M. Amaral-Phillips, J. A. Jackson, and A. A. Campbell. 2003. Health and performance of Holstein calves that suckled or were hand-fed colostrum and were fed one of three physical forms of starter. J. Dairy Sci. 86:2145-2156.

Fraser, D., D. M. Weary, E. A. Pajor, and B. N. Milligan. 1997. A scientific conception of animal welfare that reflects ethical concerns. Anim. Welf. 6:187-205.

Godden, S., J. Feirtag, L. Green, S. Wells, and J. Fetrow. 2003. A review of issues surrounding the feeding of waste milk and colostrum. Pages 49-61 in Proc. of the Minnesota Dairy Health Conference. College of Veterinary Medicine, University of Minnesota, St. Paul, $\mathrm{MN}$.

Godden, S. M., J. P. Fetrow, J. M. Freitag, L. R. Green, and S. J. Wells. 2005. Economic analysis of feeding pasteurized non-salable milk versus conventional milk replacer to dairy calves. J. Am. Vet. Med. Assoc. 226:1547-1554.

Hänninen, L., A. M. de Passillé, and J. Rushen. 2005. The effect of flooring type and social grouping on the rest and growth of dairy calves. Appl. Anim. Behav. Sci. 91:193-204.

Hänninen, L., H. Hepola, S. Raussi, and H. Saloniemi. 2007. Effect of colostrum feeding method and presence of dam on the sleep, rest and sucking behavior of newborn calves. Appl. Anim. Behav. Sci. 112:213-222.

Hänninen, L., H. Hepola, J. Rushen, A. M. de Passillé, P. Pursiainen, V.-M. Tuure, L. Syrjälä-Qvist, M. Pyykkönen, and H. Saloniemi. 2003. Resting behaviour, growth and diarrhea incidence rate of young dairy calves housed individually or in groups in warm or cold buildings. Acta Vet. Scand. 53:21-28.

Jasper, J., and D. M. Weary. 2002. Effects of ad libitum milk intake on dairy calves. J. Dairy Sci. 85:3054-3058.

Jensen, M. B., K. S. Vestergaard, C. C. Krohn, and L. Munksgaard. 1997. Effect of single versus group housing and space allowance on responses of calves during open-field tests. Appl. Anim. Behav. Sci. $54: 109-121$.

Kehoe, S. I., B. M. Jayaro, and A. J. Heinrichs. 2007. A survey of bovine colostrum composition and colostrum management practices on Pennsylvania dairy farms. J. Dairy Sci. 90:4108-4116. 
Kertz, A. F., L. F. Reutzel, and J. H. Mahoney. 1984. Ad libitum water intake by neonatal calves in its relationship to calf starter intake, weight gain, feces score, and season. J. Dairy Sci. 67:2964-2969.

Khan, M. A., H. J. Lee, W. S. Lee, H. S. Kim, K. S. Ki, T. Y. Hur, G. H. Suh, S. J. Kang, and Y. J. Choi. 2007. Structural growth, rumen development, and metabolic and immune responses of Holstein male calves fed milk through step-down and conventional methods. J. Dairy Sci. 90:3376-3387.

Losinger, W. C., and A. J. Heinrichs. 1997. Management practices associated with high mortality among preweaned dairy heifers. J. Dairy Res. 64:1-11.

Losinger, W. C., S. J. Wells, L. P. Garber, H. S. Hurd, and L. A. Thomas. 1995. Management factors related to Salmonella shedding by dairy heifers. J. Dairy Sci. 78:2464-2472.

Malhotra, N. K. 2006. Questionnaire design and scale development. Chapter 5. Pages 176-202 in The Handbook of Marketing Research: Uses, Misuses, and Future Advances. R. Grover and M. Vriens, ed. Sage Publications Inc., Newbury Park, CA.

Mee, J. F. 2004. Managing the dairy cow at calving time. Vet. Clin. Food Anim. 20:521-546.

Misch, L. J., T. F. Duffield, S. T. Millman, and K. D. Lissemore. 2007. An investigation into the practices of dairy producers and veterinarians in dehorning dairy calves in Ontario. Can. Vet. J. 48:1249-1254.

Mourits, M., A. Dijkhuizen, R. B. M. Huirne, and D. T. Galligan. 1997. Technical and economic models to support heifer management decisions: Basic concepts. J. Dairy Sci. 80:1406-1415.

Mourits, M., C. Huirne, A. A. Dijkhuizen, A. R. Kristensen, and D. T. Galligan. 1999. Economic optimization of dairy heifer management decisions. Agric. Syst. 61:17-31.

National Farm Animal Care Council. 2009. Code of Practice for the Care and Handling of Dairy Cattle. National Farm Animal Care Council, Lacombe, Alberta, Canada.

Office of the Attorney General. 2008. Standards for Confining Farm Animals (The California Prevention of Farm Animal Cruelty Act). Initiative 2007-08-09, retrieved on 2008-09-24. Attorney General's Office, California Department of Justice, Sacramento, CA

World Organization for Animal Health. 2008. Introduction to the Recommendations for Animal Welfare. World Organization for Animal Health, Paris, France.

Pellerin, D., and D. Gilbert. 2008. La gestion des coûts de remplacement. Pages 33-44 in Guide Bovins Laitiers. Comité Bovins Laitiers. Centre de Référence en Agriculture et Agroalimentaire du Québec, Quebec, Canada.

Pew Commission. 2008. Putting Meat on the Table: Industrial Farm Animal Production in America. Report of the Pew Commission on Industrial Farm Animal Production. Pew Commission on Industrial Farm Animal Production, Washington, DC

Phillips, C. J. C. 2001. Feeding Method. Principles of Cattle Production. CABI Publishing, Wallingford, UK.

Quigley, J. D., III, C. S. T. Nyabadza, G. Benedictus, and A. Brand. 1996. Monitoring replacement rearing: Objectives and materials and methods. Pages 75-102 in Herd Health and Production Management in Dairy Practice. A. Brand, J. P. T. M. Noordhuizen, and Y. H. Schukken, ed. Wageningen Press, Wageningen, the Netherlands.

Rincker, L., L. Davis, M. Vandehaar, C. Wolf, J. Liesman, L. Chapin, and M. Weber Nielson. 2006. Effects of an intensified compared to a moderate feeding program during the preweaning phase on longterm growth, age at calving, and first lactation milk production. J. Dairy Sci. 89:438. (Abstr.)

Rushen, J., A. M. de Passillé, M. A. G. von Keyserlingk, and D. M. Weary. 2008. The Welfare of Cattle. Springer, Dordrecht, the Netherlands.
Selim, S. A., and J. S. Cullor. 1997. Number of viable bacteria and presumptive antibiotic residues in milk fed to calves on commercial dairies. J. Am. Vet. Med. Assoc. 211:1029-1035.

Shamay, A., D. Werner, U. Moallem, H. Barash, and I. Bruckental. 2005. Effect of nursing management and skeletal size at weaning on puberty, skeletal growth rate, and milk production during first lactation of dairy heifers. J. Dairy Sci. 88:1460-1469.

Stafford, K. J., and D. J. Mellor. 2005. Dehorning and disbudding stress and its alleviation in calves. Vet. J. 169:337-349.

Svensson, C., K. Lundborg, U. Emanuelson, and S. O. Olsson. 2003. Morbidity in Swedish dairy calves from birth to 90 days of age and individual calf-level risk factors for infectious diseases. Prev. Vet. Med. 58:179-197.

Sylvester, S. P., D. J. Mellor, K. J. Stafford, R. A. Bruce, and R. N. Ward. 1998. Acute cortisol responses of calves to scoop dehorning using local anaesthesia and/or cautery of the wound. Aust. Vet. J. $76: 118-122$.

USDA. 1994. National Dairy Heifer Project 1991-1992: Dairy Heifer Morbidity, Mortality, and Health Management Focusing on Preweaned Heifers. USDA, National Animal Health Monitoring System, Fort Collins, CO.

USDA. 1997. Dairy 1996, Part III: Reference of Dairy Cattle Health and Health Management Practices in the United States, 1996. USDA, National Animal Health Monitoring System, Fort Collins, $\mathrm{CO}$.

USDA. 2003. Part III: Reference of Dairy Cattle Health and Health Management Practices in the United States, 2002. USDA, National Animal Health Monitoring System, Fort Collins, CO.

USDA. 2008. Dairy 2007, Part III: Reference of Dairy Cattle Health and Management Practices in the United States, 2007. USDA, National Animal Health Monitoring System, Fort Collins, CO.

Valacta. 2007. Évolution de la production laitière québécoise 2006. Page 74 in Le Producteur de Lait Québécois, Numéro Spécial. Fédération des producteurs de lait du Québec (FPLQ), Longueuil, Quebec, Canada.

Vasseur, E., J. Rushen, and A. M. de Passillé. 2009a. Does a calf's motivation to ingest colostrum depend on time since birth, calf vigor or provision of heat? J. Dairy Sci. 92:3915-3921.

Vasseur, E., J. Rushen, A. M. de Passillé, D. Lefebvre, G. Fecteau, and D. Pellerin. 2009b. A diagnostic tool to assess calf welfare and management on-farm. J. Dairy Sci. 92(E-Suppl. 1):501-502. (Abstr.)

Vickers, K. J., L. Niel, L. M. Kiehlbauch, and D. M. Weary. 2005. Calf response to caustic paste and hot-iron dehorning using sedation with and without local anesthetic. J. Dairy Sci. 88:1454-1459.

von Keyserlingk, M. A. G., and D. M. Weary. 2007. Maternal behavior in cattle. Horm. Behav. 52:106-113.

Weary, D. M., J. Jasper, and M. Hötzel. 2008. Understanding weaning distress. Appl. Anim. Behav. Sci. 110:24-41.

Weaver, D. M., J. W. Tyler, D. C. VanMetre, D. E. Hostetler, and G. M. Barrington. 2000. Passive transfer of colostral immunoglobulins in calves. J. Vet. Intern. Med. 14:569-577.

Webster, J. 2005. The assessment and implementation of animal welfare: Theory into practice. Rev. Sci. Tech. Off. Int. Epiz. 24:723-734.

Windsor, P. A., and R. J. Whittington. 2009. Evidence for age susceptibility of cattle to Johne's disease. Vet. J. doi:10.1016/j. tvj1.2009.01.007

Yeates, J. W., and D. C. J. Main. 2008. Assessment of positive welfare: A review. Vet. J. 175:293-300. 


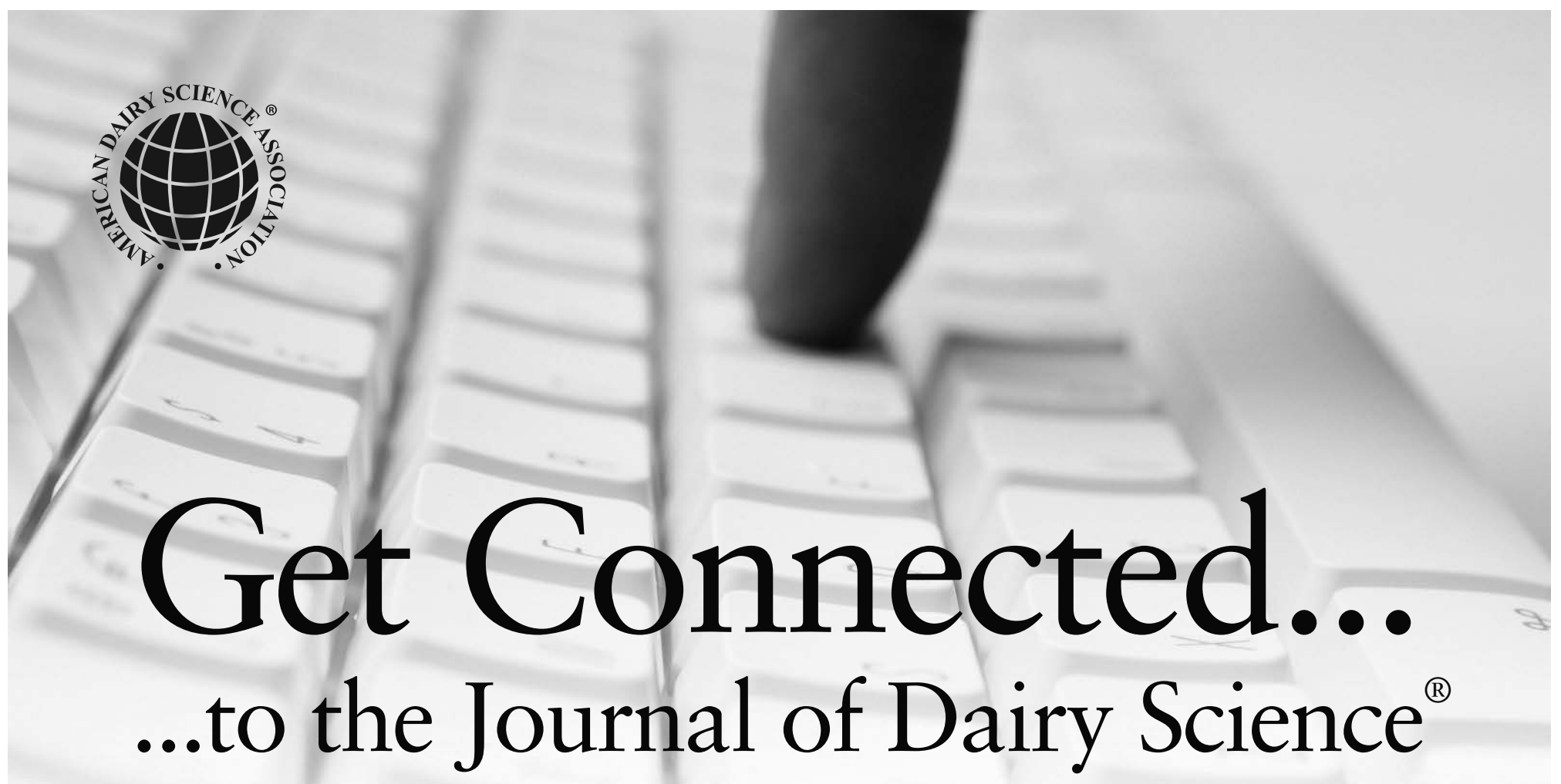

One of the primary benefits of your membership in the American Dairy Science Association ${ }^{\circledR}$ is online access to every issue of the Journal of Dairy Science ${ }^{\circledR}$ (JDS) published, from 1917 through the present. With a quick, one-time registration, you will be granted full access to all articles and be able to customize the journal site to meet your particular journal needs.

\section{Get all this online}

- Read articles whenever you want, wherever you want

- Search this journal as well as all Elsevier journals on this platform and MEDLINE with one click

- Access reference linking to find FREE content from related Elsevier publications

- Activate e-mail alerts and RSS feeds to bring the latest content straight to your inbox

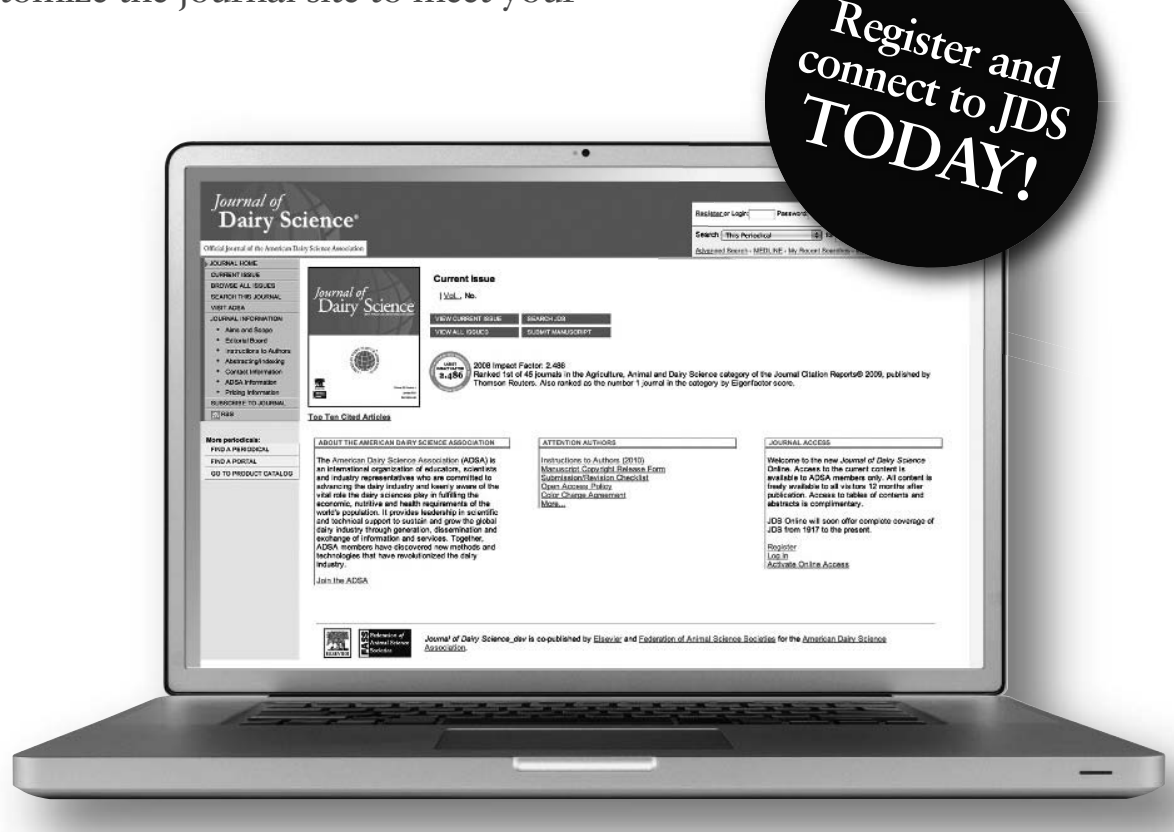

www.journalofdairyscience.org

\section{ACCESS QUESTIONS?}

Please contact our

Customer Service Department:

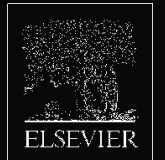

North America and Rest of World

Hours: Monday to Friday, 7:30 am - 6:00 pm, EST

Tel: (800) 654-2452 (toll-free, US \& Canada)

Tel: (314) 447-8871 (outside US \& Canada)

E-mail: JournalsOnlineSupport-usa@elsevier.com
Europe

Hours: Monday to Friday, 8:30 am - 5:00 pm, GMT

Tel: +44 (0) 1865-843177

E-mail: eurosupport@elsevier.com 